\title{
The Significance and Role of Tour Guide Association in China-Under the Background of Tourism Law
}

\author{
Xiaocan Yu \\ School of Management, Jinan University, Guangzhou, China \\ Email: debbiew@163.com
}

How to cite this paper: Yu X.C. (2017) The Significance and Role of Tour Guide Association in China-Under the Background of Tourism Law. Journal of Service Science and Management, 10, 150-155.

https://doi.org/10.4236/jssm.2017.102013

Received: February 24, 2017

Accepted: April 14, 2017

Published: April 17, 2017

Copyright $\odot 2017$ by author and Scientific Research Publishing Inc. This work is licensed under the Creative Commons Attribution International License (CC BY 4.0).

http://creativecommons.org/licenses/by/4.0/

\begin{abstract}
Tourism Law has had a significant impact on tour guides since it is implemented on October 1, 2013. This paper is intended to make a preliminary analysis of the Tour Guide Association (TGA). First, it will introduce the concept of the TGA and the problems of current management system. Then, the necessities and difficulties of setting up a TGA under the background of Tourism Law will be analyzed. Finally, this paper focuses on the discussion of the function of TGA including exchanging, rights protection, training and propaganda to promote the development of TGA.
\end{abstract}

\section{Keywords}

Tour Guide, Tour Guide Association, Tourism Law

\section{Introduction}

Tour guides are important participants in the development of tourism industry. They are "beautiful angel" who promote tourist destinations and bring happiness to tourists. Tour guides contact with tourists the most direct and the longest time compared to other tourism staffs and leave the most lasting impression to tourists. Tour guide's service quality determines the perceived service quality of tourists and it could even affect tourists' behavioral intention in the future [1].

The tourism law of the People's Republic of China (This article referred to as "Tourism Law") was voted to pass by Standing Committee of the National People's Congress on April 25, 2013 and was formally implemented on October 1. Tourism Law is the important milestone in the development of tourism in China. It has important influence on the travel service industry. It is conducive to better protect the legitimate rights and interests of tourism subjects, standardize the order of tourism market, and promote the sustainable and healthy 
development of tourism industry in China. Tourism Law for the regulation of tour guides is more specific, not only ensures the rights and interests of the general guides, as well as its interests certain restrictions. Starting whit the literature review of current management system in China, this study described problems existed in the guide's service and the current management system, and analyzed the definition and significance of Tour Guide Association (TGA). Next, difficulties of establishing the tour guide association under the background of Tourism Law were discussed and some solutions were given. Finally, this paper points out the role of the tour guide association.

\section{Review of the Current Management System's Problem}

The main problem of tour guide's management system in Chinese Mainland has four aspects. First, some of the tour guides induce, cheat even force tourists to shop and to take part in the projects need visitors to pay. They often cut down the sightseeing time. Second, travel agents don't pay to tour guides basic salary. They don't provide social security for tour guides. Third, guide supervision appraisal system is not perfect. Fourth, there are shortcomings in terms of tour guide training, service supervision, positive publicity and guide, service from government and the association for tour guides [2].

The main reason of the problems is that guide management system and the system design are not reasonable. This kind of irrationality leads to that tour guides can't get the knowledge and skill training, can't gain the opportunity for career development because they don't have career planning, job skills training and guidance or sharing session. When their rights are violated, they don't have the ability to maintain their own rights and interests, and then they can't experience a sense of pride in their work.

As a result of the existence of those problems, it's necessary to establish Tour Guide Association (TGA) to cultivate good tour guide, to improve service quality, to protect the lawful rights and interests of the guide so as to play the role of industry organization. The TGA this article mentioned is an association organization which makes market-oriented operation, not linked in a government agency.

\section{The Definition and Significance of TGA}

\subsection{The Definition of TGA}

This paper argues that the TGA is a professional and non-profit social organization with legal person status consisting of full-time and part-time tour guides, tour operators and people concerned about the tour guide. The purpose of TGA is to abide by the relevant national laws, regulations and policies, abide by social morality and ethics, safeguard the legitimate rights and interests of tour guides in the TGA, service for the tour guide, travel and tourism industry, play a role of link among tour guides, government and tourism enterprises [3].

\subsection{The Practical Significance of TGA}

The current management system cannot effectively protect the legitimate rights 
and interests of the guide, unable to provide the guide systematic skills training. Therefore, we need TGA to serve for tour guides and play a role of link among government, tourism enterprises and tour guides.

\subsection{The Legal Significance of TGA}

The Article 37 of Tourism Law stipulates the condition of applying for Tour Guide Certificate, "Persons that have passed the qualification examination of tour guides and signed labor contracts with travel agencies or registered in the relevant tourism industry organizations may apply for the certificate of tour guides". "The relevant tourism industry organizations" in Tourism Law takes the place of "tour guide service company" in Guide's personnel management regulation which was effective as of October 1, 1999 and was abolished on September 27, 2016. "Tour guide service company" charges a fee to renew Tour Guide Certificate annually and almost does not provide other services. Since there is no labor contracts with the tour guide, "tour guide service company" can't effectively safeguard the legitimate rights and interests of the guide tourist guide in legal disputes. Establishing a TGA is a trend in the future. Tour guides not in travel agency not only can be legally affiliated to "tour guide service company", also can undertake registration in the related tourism industry group such as the TGA. Tourism Law provides a legal basis for the establishment of TGA.

The Article 90 of Tourism Law stipulates that "Tourism industry organizations that are established in accordance with the law shall formulate code of conduct and service quality standards of the industry consistent with laws, administrative regulations and their own constitutions, exercise self-discipline administration on the business activities and service quality of members, and organize professional ethics education and skill training to raise the quality of tourism professionals". Tourism Law regulates the working content of tourism industry organization from legal perspective and provides the legal counsel for TGA' work.

Therefore, the establishment of TGA is a response to the spirit of Tourism Law, is explore and standard for management system under the guidance of Tourism Law. It has a strong legal sense.

\section{The Difficulty of Establishing TGA}

\subsection{Funding}

Most TGA in mainland China have sole financial source. Membership fee is the main source of income for covering the Association's normal expenditures. Insufficient funds will lead to difficulty to hold some activities and affect the quality of service.

In this regard, TGA may refer to the tour guide association in Hong Kong, Australia and other places' successful experience such as using the market rules and the brand influence of TGA to increase the source of funding.TGA should try to improve the quality of service, strive for more member tour guides, then obtain more membership fees. Some executive and technical affairs are borne by 
the TGA, and the government pays a certain amount of compensation according to the difficulty and quality of the task.

\subsection{Authority}

The government management of the association is too careful before. The rights of the TGA are insufficient, so it is difficult for TGA to get rid of the status of government affiliates.

To solve the problem, governmental departments should increase the devolution of power to the TGA and allow the TGA to carry out some of the work independently according to the requirements of its development and members like the annual verification of Tour Guide Certificate or training and communication for tour guides, thus the TGA can replace some of the administrative functions and the government can concentrate on doing other things.

\subsection{Attraction}

TGA is an industry organization that tour guides willing to join. If it only charges a membership fee every year, but not to hold some activities those are helpful and attractive to guide, it will not attract more guide to join in. Therefore, we need to thinking about how to increase attraction, enhance the cohesive affinity and sense of belonging of tour guides and make TGA into a harbor that is worth guides to trust and rely.

The TGA should attract tour guides by providing targeted services. For instance, in order to promote a good career status of tour guides and to promote career advancement, it is necessary to establish a standardized vocational training system which should specify the content of the training requirements and management methods.

\section{The Role of TGA}

\subsection{Exchange}

The TGA should provide internal communication platform for guides to share ideas and information and to exchange experience. Through holding the guide salon, fellowship activities, guide advanced deeds share activities, TGA could strengthen the connection between guides and the professional identity and a sense of pride of guides. Also, it can enhance understanding consequently make TGA a real "home" of tour guide.

Except internal communication, TGA should also strengthen the relationship and cooperation with other organizations and communities in the industry to promote the healthy and sustainable development of tourism industry.

\subsection{Rights Protection}

First, TGA can conduct studies of the tourism market, management and service standards to give government departments and tourist enterprises suggestions about formulating relevant policies, operation and management. In addition, TGA can actively advocate establish tour guide salary system which determines 
the salary and allowance according to the level of tour guide, education, work experience, work quality, quantity and other conditions [4]. If so, those tour guides whit high education, high level and rich experience can enjoy a higher level of wages, thereby encouraging other guides to improve themselves continuously [5].

\subsection{Training}

The Article 35 of Tourism Law stipulates that "Travel agencies shall not lure tourists into their tour programs by offering an unreasonably low price and seek kickbacks and other illegal gains by including shopping or tourist activities that involve extra costs into their programs. When organizing and receiving tourists, travel agencies shall not designate any specific shopping site or arrange any tourist activity that involves extra costs, unless such arrangements are agreed by the two sides through consultation or demanded by the tourists and cause no interruption in the program of other tourists". And in the third paragraph of Article 60 stipulates that "Travel agencies that have arranged tour guides to provide services for the tourists must state clearly in the package tour contract the charges of tour guide services". Tourism Law cut off the "kickbacks" and "grey income" chain and let the guide's service return to the authenticity [6]. It can be seen that Tourism Law puts forward higher requirements for tour guides' professional ability such as professional ethics and legal consciousness.

Therefore, TGA should strengthen the guides' self-improvement, advocate them practice skills through the various forms of activities to compete service but not "fool". First of all, TGA can invite excellent tour guides to share their experience in communication and discussion activities. Second, TGA can invite experts to train tour guides current events and professional knowledge. In addition, the training content should include legal knowledge to strengthen their legal consciousness. Then, they can understand the laws and regulations to use legal means to protect themselves.

\subsection{Propaganda}

TGA can set up a good image of tour guides and improve their social status by participating in the tourism exhibitions, publishing trade journals, building the tour guide professional website, etc. TGA should establish a good environment in tour guides, pick out some excellent tour guides every year to praise and encourage them, and guide the healthy development of the tour guide industry.

\section{Conclusion}

Though the development of tour guide association in mainland China is not yet mature, industry association to assume part of the administrative management function, in the long run, is the inevitable trend to promote the development of tour guide industry running. The future development of tour guide association also needs the support from the whole industry to draw lessons from the advanced experience of other countries and regions, to explore the management 
methods which are adapted to the Chinese context.

\section{References}

[1] Xie, L.S. and Li, J.Y. (2007) A Study of the Relationships between Tour Guides' Service Quality and Tourists' Trust and Behavioral Intentions. Tourism Science, 4, 43-48.

[2] National Tourism Administration Supervisory Department Research Report on Tour Guide System Reform (2010, May). http://www.cnta.gov.cn

[3] Zhao, A.H. (2012) The Role the Tour Guide Association Should Play. Management and Administration, 8, 19-21.

[4] Wan, Z.X. (2014) The Exploration of Tour Guide Salary in the Background of New “Tourism Law”. Business Research, 4, 124-125.

[5] Zhao, P. (2015) Impact on Tour Guides since the Implementation of the New “Tourism Law". Legal System and Society, 13,184-185.

[6] Dong, B.B. (2014) The Influence of the Implementation of Tourism Law on Professional Tour Guides. Journal of Liming Vocational University, 2, 16-23.

Submit or recommend next manuscript to SCIRP and we will provide best service for you:

Accepting pre-submission inquiries through Email, Facebook, LinkedIn, Twitter, etc. A wide selection of journals (inclusive of 9 subjects, more than 200 journals)

Providing 24-hour high-quality service

User-friendly online submission system

Fair and swift peer-review system

Efficient typesetting and proofreading procedure

Display of the result of downloads and visits, as well as the number of cited articles

Maximum dissemination of your research work

Submit your manuscript at: http://papersubmission.scirp.org/

Or contact jssm@scirp.org 